\title{
STUDI EMPIRIS PERILAKU USAHA KOPERASI PERTANIAN: KASUS KOPERASI DI DATARAN TINGGI GAYO, PROVINSI ACEH
}

\author{
Devi Agustia*), Nunung Kusnadi**), dan Harianto $\left.{ }^{* * *}\right)$ \\ *) Program Studi Ilmu Ekonomi Pertanian, Sekolah Pascasarjana Institut Pertanian Bogor \\ Gedung FEM Lantai 2, Jl. Kamper, Kampus IPB Dramaga, Bogor 16680 \\ **) Departemen Ilmu Ekonomi, Fakultas Ekonomi dan Manajemen, Institut Pertanian Bogor \\ Gedung FEM Lantai 2, Jl. Kamper, Kampus IPB Dramaga, Bogor 16680 \\ ${ }^{* * *}$ Departemen Agribisnis, Fakultas Ekonomi dan Manajemen, Institut Pertanian Bogor \\ Jl. Kamper, Wing 4 Level 5, Kampus IPB Dramaga, Bogor 16680
}

\begin{abstract}
Agricultural cooperatives play an important role in supporting small agricultural farmers. The key roles of cooperatives are to improve access to markets, increase in bargaining position of farmers, and adopt improved technologies. The problem faced by the coffee farmers is their weakness position in the price determination. Based on this problem, this study aimed to analyze the cooperative's business behavior. The study was conducted in Aceh Tengah and Bener Meriah districts. Data were collected from 15 cooperatives purposively selected. The mode of cooperative economic behavior was constructed as a simultaneous equation system consisting of purchase price, purchase amounts, sales prices and number of cooperative members. The model was estimated by 2SLS method. The results show that most of the variables in the model indicate that cooperatives have run their business in compliance with the cooperative principles.
\end{abstract}

Keywords: agricultural cooperative, coffee, farmers, simultaneous model

\begin{abstract}
ABSTRAK
Koperasi pertanian memiliki peran penting dalam mendukung petani kecil. Peran kunci koperasi tersebut, yaitu untuk meningkatkan akses pasar, meningkatkan posisi tawar petani, dan meningkatkan kemampuan mengadopsi teknologi. Masalah yang dihadapi petani kopi adalah posisi tawar petani lemah dalam penentuan harga. Penelitian ini bertujuan mengetahui perilaku usaha koperasi dengan menganalisis faktor-faktor yang memengaruhi harga pembelian, jumlah pembelian, jumlah penjualan, jumlah anggota dan sisa hasil usaha pada koperasi. Model perilaku ekonomi koperasi dibangun sebagai suatu sistem persamaan simultan yang terdiri dari harga pembelian, jumlah pembelian, harga penjualan, jumlah anggota koperasi dan Sisa hasil usaha. Model ini diestimasi dengan metode 2SLS. Hasil analisis menunjukkan bahwa sebagian besar variabel dalam model menunjukkan bahwa koperasi telah menjalankan kegiatan usahanya sesuai dengan prinsip-prinsip koperasi. Hal ini ditunjukkan dari perilaku koperasi dalam melakukan pembelian terhadap kopi anggota.
\end{abstract}

Kata kunci: koperasi pertanian, kopi, petani, model simultan

${ }^{1}$ Alamat Korespondensi:

Email: devie.agustya@gmail.com

\section{PENDAHULUAN}

Koperasi dalam perekonomian Indonesia mempunyai kedudukan dan peran yang sangat strategis dalam pertumbuhan dan pengembangan potensi ekonomi rakyat. Ketaren (2007) menyatakan bahwa peranan koperasi dalam perekonomian secara makro adalah meningkatkan manfaat sosial dan ekonomi bagi masyarakat dan lingkungan, meningkatkan produksi, pendapatan, kesejahteraan, dan meningkatkan kesempatan kerja. Peran koperasi akan meningkat ditandai dengan kesadaran yang semakin tinggi di 
kalangan masyarakat untuk membangun kekuatan berdasarkan collective bargaining (Wijaya, 2004). Berdasarkan data Kementerian Koperasi dan UKM dalam BPS (2015), koperasi di Indonesia mengalami peningkatan, dimana pada 2008 total koperasi sebanyak 154 ribu unit meningkat menjadi 209 ribu unit pada 2014. Demikian juga jumlah anggota koperasi tahun 2008 berjumlah 27,3 ribu anggota meningkat sebesar 29\% menjadi 36,4 ribu anggota pada tahun 2014.

Pada umumnya koperasi memiliki keunggulan di bidang pertanian. Keunggulan koperasi tersebut memperbaiki posisi tawar (bargaining position) petani, membuka akses pasar baru untuk produk petani, dan meningkatkan kemampuan dalam mengadopsi teknologi. Salah satu komoditas pertanian yang memiliki potensi untuk dikembangkan adalah kopi Arabika. Provinsi Aceh merupakan salah satu penghasil utama kopi Arabika di Indonesia. Koperasi pertanian di Provinsi Aceh telah berperan dalam mengorganisir usaha tani kopi Arabika (Hasan, 2014). Selain mengorganisir usaha tani, koperasi juga diharapkan mampu meningkatkan bargaining position petani dengan cara petani melakukan penjualan dan menentukan harga secara bersama-sama sehingga diharapkan dapat memperoleh harga yang lebih baik. Tahun 2013 jenis kopi Arabika telah dikembangkan oleh petani pada areal seluas 48 ribu ha di Kabupaten Aceh Tengah dan 43 ribu ha di Kabupaten Bener Meriah (Disbun Provinsi Aceh, 2013). Meskipun tanaman kopi telah banyak diusahakan, namun masalah mendasar yang dihadapi petani adalah harga kopi yang diterima petani cenderung rendah. Hal ini dapat dilihat pada Gambar 1.

Berdasarkan Gambar 1 terlihat bahwa ada disparitas harga antara petani dengan eksportir. Harga kopiArabika di tingkat petani relatif stabil berkisar antara Rp8.000 sampai Rp13.000 per kg, sedangkan harga di tingkat eksportir mengalami perubahan relatif besar berkisar antara Rp30.000 sampai Rp50.000. Ini menunjukkan bahwa selama tahun 2006-2013 harga di tingkat petani dan harga di tingkat eksportir memiliki gap yang semakin lama semakin melebar dari waktu ke waktu. Hal ini mengindikasikan keberadaan koperasi belum dirasakan manfaatnya khususnya dalam peningkatan bargaining position petani.
Hal yang sama juga ditunjukkan dari beberapa penelitian sebelumnya bahwa koperasi belum berperan dalam meningkatkan kesejahteraan petani dimana bargaining position petani lemah dalam penentuan harga dan koperasi belum mampu meningkatkan bargaining position petani (Saputra, 2012; Subari, 2012; Putri et al. 2013). Agar koperasi dirasakan manfaatnya, maka koperasi harus memperbaiki perilaku usahanya. Perilaku usaha koperasi menjadi kajian penting dalam mempelajari koperasi dan ekonomi pertanian (Murray, 1983; Sexton, 1984). Perilaku usaha koperasi pada dasarnya merupakan perilaku ekonomi koperasi dalam melakukan kegiatan usahanya sesuai dengan prinsipprinsip koperasi. Beberapa penelitian mengkaji perilaku usaha koperasi (Krishnamurti, 1998; Katz, 1997; Goldsmith, 1995; Cook, 1994; Levay, 1987; Staatz, 1987). Dengan mempelajari perilaku usaha koperasi akan diketahui sejauhmana konsep-konsep dalam teori ekonomi diterapkan dalam menjalankan kegiatan usaha koperasi.

Perilaku usaha dalam penelitian ini adalah proses pengambilan keputusan ekonomi oleh koperasi yang akan mengarahkan perkembangan kegiatan koperasi sebagai suatu badan usaha disamping perilaku koperasi sebagai lembaga sosial. Sebagai suatu badan usaha koperasi bertujuan memaksimalkan keuntungan (profit oriented), sedangkan sebagai lembaga sosial koperasi mempunyai tujuan memaksimalkan pelayanan (service oriented). Koperasi sebagai lembaga sosial akan meningkatkan perannya dalam memberikan pelayanan kepada anggota terutama dalam melakukan pembelian kopi dengan harga yang lebih tinggi dan jumlah yang lebih banyak. Sebagai badan usaha, koperasi adalah sebuah perusahaan yang harus mampu berdiri sendiri menjalankan kegiatan usahanya untuk memperoleh laba. Laba dalam koperasi dikenal dengan istilah Sisa Hasil Usaha (SHU). Peningkatan sisa hasil usaha dari suatu koperasi sangat tergantung pada kegiatan yang dijalankannya yaitu dari pembelian kopi dari anggota dan penjualan kopi tersebut. Melihat pentingnya peran koperasi maka penelitian ini bertujuan mengetahui perilaku usaha koperasi dengan menganalisis faktorfaktor yang memengaruhi harga pembelian, jumlah pembelian, jumlah penjualan, jumlah anggota dan sisa hasil usaha pada koperasi. 


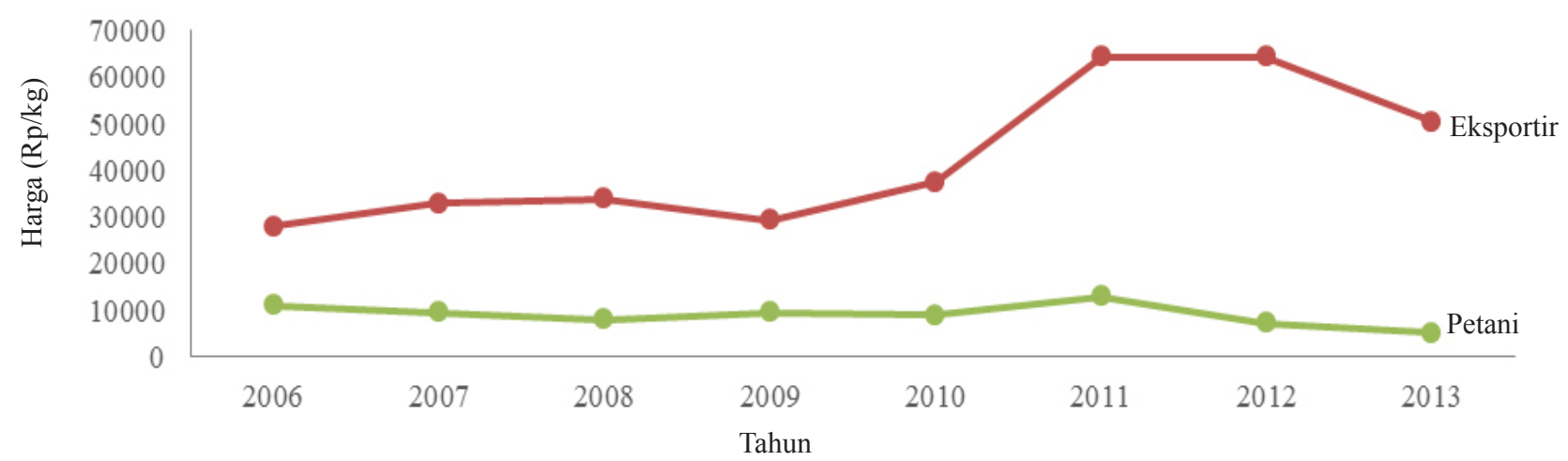

Gambar 1. Pergerakan harga kopi Arabika Gayo di tingkat petani, dan eksportir tahun 2006-2013 (Disbun Provinsi Aceh, 2013; Disperindag dan UKM Provinsi Aceh, 2013)

\section{METODE PENELITIAN}

Penelitian ini dilaksanakan di Provinsi Aceh yang merupakan salah satu penghasil utama kopi Arabika, dimana Kabupaten Aceh Tengah dan Kabupaten Bener Meriah sebagai sentra produksi. Pemilihan lokasi dilakukan secara sengaja (purposive) dengan pertimbangan kedua kabupaten tersebut merupakan sentra produksi kopi di Provinsi Aceh dan hampir keseluruhan petani kopi Arabika tergabung dalam koperasi. Selain itu, koperasi yang terdapat di kedua kabupaten tersebut memiliki potensi yang besar dan strategis untuk dikembangkan.

Jenis data yang digunakan dalam penelitian ini adalah kombinasi data cross section dan data time series (pool data). Data yang digunakan dalam penelitian ini merupakan data sekunder dimana data yang dikumpulkan data profil koperasi dan hasil Laporan Rapat Anggota Tahunan (RAT) tahun buku 2011-2014. Selain itu juga dikumpulkan berbagai data sekunder lain dari jurnal ilmiah, tesis, disertasi, dokumen dan publikasi dari instansi terkait.

Unit analisis dalam penelitian ini adalah koperasi. Koperasi yang dianalisis adalah seluruh koperasi yang bergerak dalam pemasaran kopi di Kabupaten Aceh Tengah dan Bener Meriah, yaitu sebanyak 21 unit. Dari jumlah 21 unit koperasi tersebut hanya difokuskan pada koperasi yang telah melakukan Rapat Anggota Tahunan (RAT) tahun 2014 dan telah melakukan pemasaran kopi selama tiga tahun terakhir, yaitu sebanyak 15 unit koperasi.

Analisis perilaku usaha koperasi dalam penelitian ini menggunakan model ekonometrika dengan sistem persamaan simultan, yang terdiri dari lima persamaan struktural seperti terlihat pada Tabel 1. Pendugaan model menggunakan metode Two Stage Least Square (2SLS). Pengolahan data menggunakan program komputer SAS 9.3. Persamaan simultan yang di bangun berdasarkan teori serta penelitian sebelumnya, dan hipotesis penelitian dapat dilihat pada Tabel 1 .

Tabel 1. Model persamaan simultan perilaku usaha koperasi

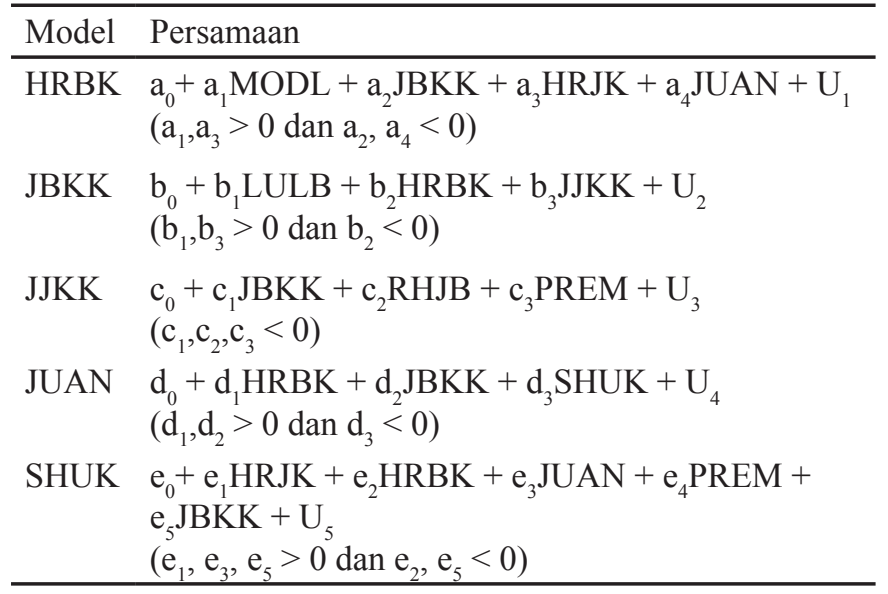

\section{Keterangan:}

HRBK $=$ Harga pembelian kopi koperasi $(\mathrm{Rp})$; MODL= Modal koperasi $(\mathrm{Rp}) ; \mathrm{JBKK}=$ Jumlah pembelian kopi koperasi (Kg); HRJK = Harga penjualan kopi koperasi (Rp); JUAN = Jumlah anggota koperasi (Orang); LULB $=$ Luas lahan binaan koperasi (Ha); JJKK = Jumlah penjualan kopi koperasi (Kg); RHJB = Rasio harga jual dan harga beli kopi koperasi; PREM $=$ Premium fee $(\mathrm{Rp})$; SHUK $=$ Sisa hasil usaha koperasi (Rp).

Hipotesis dalam penelitian ini adalah koperasi telah berperan dalam meningkatkan bargaining position petani melalui perilaku usahanya. Perilaku usaha koperasi dalam menjalankan kegiatan usahanya sesuai dengan fungsi dan perannya menunjukkan koperasi telah berjalan sesuai dengan prinsip-prinsip koperasi. 


\section{HASIL}

\section{Perkembangan Koperasi di Dataran Tinggi Gayo}

Koperasi selama ini telah berkembang sesuai dengan potensi yang dimiliki. Koperasi telah mampu mengelola sumber daya yang dimiliki dengan baik meskipun dengan keterbatasan baik dari aspek manajemen usaha maupun dari sarana yang dimiliki dalam menjalankan usahanya. Dataran tinggi Gayo merupakan salah satu dataran tinggi yang terdapat di Provinsi Aceh. Nama Gayo berasal dari nama suku yang mendiami wilayah tersebut. Secara administratif dataran tinggi Gayo meliputi wilayah Kabupaten Aceh Tengah, Kabupaten Bener Meriah dan Kabupaten Gayo Lues. Koperasi di dataran tinggi Gayo telah berdiri selama kurun waktu 3 sampai 16 tahun. Koperasi yang telah lama berdiri menunjukkan bahwa koperasi tersebut mampu untuk bertahan dan terus melakukan usaha pemasaran kopi, dan koperasi ini juga cenderung memiliki jumlah anggota lebih banyak. Jumlah anggota sangat berperan dalam mengumpulkan modal koperasi. Rata-rata jumlah anggota koperasi adalah sebesar 1.732 orang dengan luas lahan rata-rata sebesar \pm 1.955 ha. Jumlah anggota dan luas lahan akan mendukung kelancaran usaha perdagangan kopi, karena jumlah anggota menjamin tersedianya produksi kopi koperasi. Adapun perkembangan koperasi yang melakukan pemasaran kopi di Kabupaten Aceh Tengah dan Bener Meriah dapat dilihat pada Tabel 2.
Secara umum, koperasi yang terdapat di dataran tinggi Gayo telah memiliki rata-rata modal sebesar Rp733.436.140. Koperasi dengan modal kurang dari Rp100 juta rupiah sebanyak 33,33\% dan Rp200 juta Rp300 juta rupiah sebanyak 33,33\%. Modal diperoleh dari simpanan pokok dan simpanan wajib. Simpanan pokok merupakan sejumlah uang yang wajib dibayarkan oleh anggota pada koperasi saat masuk menjadi anggota. Modal ini digunakan untuk operasional koperasi dan pembelian kopi dari anggota.

Rata-rata omset koperasi mencapai 46 milyar rupiah pada tahun 2014. Omzet diperoleh dari jumlah penjualan kopi pada harga penjualan. Penjualan kopi oleh koperasi adalah dalam bentuk kopi asalan yaitu dengan kadar air $11-13 \%$. Kegiatan penjualan kopi yang dilakukan koperasi yaitu dengan penjualan langsung (lokal) dan penjualan dengan sistem kontrak. Setiap koperasi memiliki kapasitas penjualan dan pembelian kopi yang berbeda-beda, faktor penentu jumlah pembelian dan penjualan kopi diantaranya adalah luas lahan binaan koperasi dan jumlah kontrak yang dilakukan koperasi. Pada tahun 2014 rata-rata jumlah pembelian kopi oleh koperasi sebanyak 1.615.676 kg. Koperasi dengan jumlah pembelian terendah memiliki luas lahan kedua terkecil dari luas lahan binaan koperasi lainnya. Ratarata jumlah penjualan kopi oleh koperasi adalah 722.223 $\mathrm{kg}$. Koperasi dengan jumlah penjualan terendah ini dikarenakan koperasi ini baru melakukan perpanjangan sertifikasi sehingga pada saat proses perpanjangan belum bisa melakukan kontrak penjualan.

Tabel 2. Perkembangan koperasi di Kabupaten Aceh Tengah dan Bener Meriah tahun 2014

\begin{tabular}{lrrrr}
\hline \multicolumn{1}{c}{ Indikator } & \multicolumn{1}{c}{ Rata-rata } & \multicolumn{1}{c}{ Std dev } & Minimum & \multicolumn{1}{c}{ Maksimum } \\
\hline Umur (tahun) & 7,8 & 3,42 & 3 & 16 \\
Anggota (orang) & 1.732 & $1.277,57$ & 494 & 5.810 \\
Luas lahan (Ha) & $1.955,44$ & $1.590,24$ & 474,75 & $7.114,82$ \\
Modal (Rp) & 733.436 .140 & 843.932 .130 & 22.559 .000 & 2.601 .218 .000 \\
Omset (Rp) & 46.229 .135 .419 & 43.275 .758 .594 & 7.199 .500 .000 & 168.108 .554 .645 \\
SHU (Rp) & 338.111 .477 & 412.908 .288 & 3.130 .250 & 1.482 .076 .062 \\
Premium fee (Rp) & 2.471 .840 .659 & 2.262 .708 .125 & 200.200 .000 & 8.121 .329 .994 \\
Jumlah beli (kg) & $1.615 .676,2$ & $1.552 .487,5$ & 270.000 & 6.251 .775 \\
Jumlah jual (kg) & $722.223,3$ & $610.834,3$ & 129.600 & 2.222 .400 \\
Harga beli (Rp/kg) & $26.911,09$ & $3.985,30$ & 19.975 & 35.482 \\
Harga jual (Rp/kg) & $61.133,85$ & $9.269,12$ & 50.000 & 79.650 \\
\hline
\end{tabular}


Pada Tabel 2 juga dapat dilihat bahwa rata-rata nilai SHU pada koperasi, yaitu sebesar Rp338.111.477. Sebagian besar $(73,33 \%)$ SHU total koperasi yang terdapat di kedua kabupaten lebih dari 50 juta rupiah. SHU ini diperoleh dari kegiatan perdagangan kopi oleh koperasi, yaitu dengan membeli kopi dalam bentuk gabah dari anggota dan kemudian menjual ke pembeli (eksportir/importir) dalam bentuk greenbean (biji kopi asalan kadar air 11-13\%). Dalam melakukan kegiatan usahanya peran yang dilakukan oleh koperasi meliputi pengumpulan, penjemuran, sortasi/ grading, penyimpanan, pengolahan, transportasi, dan pengemasan. Peran ini sebagai upaya dalam pembentukan SHU koperasi.

Penelitian Mujibburahman (2011) menyatakan dengan melaksanakan peran tersebut, koperasi mampu menciptakan nilai tambah bersih sebesar 59,5\% dari total biaya yang dikeluarkan. Selain SHU koperasi juga memperoleh Premium fee. Premium fee koperasi diperoleh dari penjualan kopi dengan sertifikasi fairtrade. Premium fee ini merupakan uang lebih yang harus dikeluarkan oleh buyer di luar negeri untuk keperluan bisnis petani atau pembangunan lingkungan sekitar petani bermukim, seperti jalan atau sarana umum lainnya. Pada tahun 2014 rata-rata premium fee yang diperoleh koperasi sebesar Rp2.471.840.659. Terdapat tiga unit koperasi (20,00\%) memperoleh premium fee lebih dari Rp5 milyar rupiah. Penggunaan premium fee dialokasikan $25 \%$ untuk lingkungan, sisanya untuk anggota dan kegiatan koperasi. Semakin banyak jumlah penjualan maka semakin banyak pula premium fee yang diperoleh.

\section{Analisis Perilaku Usaha Koperasi}

\section{Harga Pembelian}

Harga pembelian kopi koperasi (HRBK) merupakan harga pembelian kopi anggota oleh koperasi. Variabel jumlah pembelian memiliki tanda parameter dugaan negatif dan signifikan terhadap harga pembelian pada taraf $\alpha 0,05$. Hal ini menunjukkan bahwa tinggi rendahnya harga pembelian di tentukan oleh jumlah pembelian koperasi. Hasil analisis ini sesuai perilaku koperasi dalam melakukan kegiatan pembelian. Penentuan harga pada koperasi (Helmberger dan Hoos, 1962) yaitu apabila koperasi bertindak sebagai pembeli (menampung hasil anggota) melakukan peningkatan pembelian maka akan terjadi penurunan terhadap harga pembelian koperasi.
Variabel harga jual koperasi (HRJK) memiliki tanda parameter dugaan positif dan signifikan terhadap harga pembelian koperasi pada taraf $\alpha \quad 0.01$. Hasil ini sesuai dengan tujuan koperasi dalam memberikan pelayan kepada anggota dalam hal ini harga beli kopi oleh koperasi kepada anggota. Hasil penelitian, koperasi melakukan pembelian kopi berdasarkan harga pasar. Namun, koperasi tetap mempertimbangankan harga jualnya berdasarkan harga kontrak. Ketika harga jual tinggi maka koperasi masih dapat melakukan pembelian sesuai dengan harga pasar dan koperasi dapat pula melakukan pembelian dengan harga lebih tinggi dari harga pasar, selama harga beli tersebut tidak melebihi harga jual koperasi. Hasil ini sesuai dengan penelitian Wollni dan Zeller (2007) yang menyatakan bahwa harga beli koperasi terhadap produk anggota lebih tinggi dari harga pasar.

Variabel jumlah anggota koperasi (JUAN) memiliki tanda parameter dugaan positif dan tidak berpengaruh signifikan terhadap harga pembelian koperasi. Arah pengaruh jumlah anggota koperasi memberikan tanda parameter yang tidak sesuai dengan hipotesis yang diharapkan terhadap harga pembelian kopi koperasi. Namun, hasil analisis yang tidak sesuai dengan hipotesis dan teori ini dapat dijelaskan dengan kondisi lapangan bahwa perubahan jumlah anggota koperasi dari waktu ke waktu tidak secepat perubahan harga. Jumlah anggota memiliki peluang yang kecil untuk berubah dalam waktu cepat (per minggu), tetapi fluktuasi harga dapat dikatakan setiap hari bahkan setiap jam dapat berubah. Penelitian ini memberikan hasil yang berbeda dari teori yang dikemukakan oleh Dahl dan Hammond (1997) dimana jumlah anggota yang semakin bertambah akan meningkatkan jumlah produk ditawarkan anggota sehingga harga yang dibayarkan koperasi kepada anggota akan mengalami penurunan.

Variabel modal koperasi (MODL) tidak berpengaruh signifikan terhadap harga pembelian kopi koperasi. Arah pengaruh modal koperasi memberikan tanda parameter yang tidak sesuai dengan hipotesis yang diharapkan yaitu negatif terhadap harga pembelian kopi koperasi. Ini menunjukkan bahwa besar kecilnya modal tidak menentukan harga pembelian koperasi. Hal ini dikarenakan harga pembelian kopi koperasi mengacu pada harga pasar dengan mempertimbangkan harga penjualannya. Selain itu hasil temuan dilapangan menunjukkan koperasi dalam melakukan kegiatan usahanya masih mengandalkan modal dari luar 
(pinjaman). Pengeluaran terbesar koperasi pada umumnya dibutuhkan pada saat melakukan pembelian kopi gabah dari petani anggota. Selanjutnya, koperasi melakukan proses pengolahan kopi gabah menjadi kopi dalam bentuk greenbean yang siap untuk dijual. Biaya yang dikeluarkan koperasi untuk proses perubahan bentuk kopi tersebut sebesar Rp900 per kg. Sehingga koperasi dalam memenuhi satu kontainer (19.200 kg) kopi greenbean memerlukan modal sebesar satu hingga dua milyar rupiah untuk membeli kopi gabah dan biaya proses kopi tersebut. Besarnya modal yang dibutuhkan mendorong koperasi untuk melakukan pinjaman. Hasil ini memiliki kesamaan dengan penelitian Sarjana et al. (2013) yang menyatakan dalam pengelolaan modal koperasi masih mengandalkan pembelanjaannya dengan dana dari pinjaman. Selain itu, penelitian Hasan (2014) memberikan rekomendasi sebagai strategi untuk pemberdayaan koperasi pertanian salah satunya adalah bantuan permodalan. Hasil pendugaan parameter faktor-faktor yang memengaruhi harga pembelian kopi selengkapnya pada Tabel 3.

\section{Jumlah Pembelian}

Jumlah pembelian kopi koperasi (JBKK) merupakan jumlah kopi yang dibeli koperasi dari anggota. Hasil analisis menunjukkan keseluruhan variabel memiliki tanda parameter dugaan sesuai dengan hipotesis perilaku koperasi dan berpengaruh signifikan terhadap jumlah pembelian pada taraf $\alpha$ yang berbeda. Hasil analisis variabel luas lahan binaan koperasi (LULB) memiliki pengaruh positif terhadap jumlah pembelian kopi koperasi, dan pengaruh tersebut signifikan pada taraf $\alpha$ 0,05. Pada penelitian ini luas lahan adalah proxy dari jumlah penawaran kopi dari anggota. Luas lahan merupakan salah satu faktor yang memengaruhi produksi. Temuan lapangan menunjukkan bahwa saat koperasi melakukan kontrak dengan buyer, koperasi melakukan negosiasi dengan mempertimbangkan jumlah produksi. Rata-rata luas lahan binaan koperasi di lokasi penelitian 1.955 ha dengan luas lahan binaan terkecil mencapai 474 ha dan terbesar mencapai 7.114 ha dengan produksi kopi sebesar $4.800 \mathrm{~kg} / \mathrm{ha}$ hingga $5.500 \mathrm{~kg} /$ ha per tahun. Hal ini juga di dukung hasil penelitian Fatwa (2011) yang menyatakan luas lahan berpengaruh positif dan signifikan terhadap hasil produksi kopi di Kabupaten Aceh Tengah.

Variabel jumlah penjualan kopi koperasi (JJKK) memiliki tanda parameter dugaan positif dan signifikan terhadap jumlah pembelian koperasi pada taraf taraf $\alpha$ 0,01 Hal ini menunjukkan bahwa tinggi rendahnya jumlah pembelian di tentukan oleh jumlah penjualan koperasi. Penjualan kopi biasanya dilakukan koperasi melalui sistem kontrak, yaitu kesepakatan transaksi baik terkait jumlah dan harga dilakukan minimal satu bulan sebelum kopi dikirim. Selain sistem kontrak, koperasi menjual kopi secara konvensional (pasar lokal) namun dalam jumlah tidak banyak. Beberapa koperasi yang memiliki kapasitas gudang dan modal yang cukup juga melakukan pembelian melebihi jumlah kontrak penjualan untuk persediaan kopi di koperasi. Dengan demikian, semakin banyak jumlah penjualan yang dilakukan koperasi maka semakin banyak pula jumlah pembelian kopi anggota oleh koperasi.

Tabel 3. Hasil pendugaan parameter faktor-faktor yang memengaruhi harga pembelian kopi

\begin{tabular}{lcccc}
\hline \multicolumn{1}{c}{ Variabel } & Simbol & Parameter dugaan & $\mathrm{P}>|\mathrm{t}|$ & Elastisitas \\
\hline Modal koperasi & MODL & $-5,18 \mathrm{E}-8$ & 0,3935 & $-0,0058$ \\
Jumlah pembelian koperasi & JBKK & $-0,00236$ & $0,0136^{\mathrm{b}}$ & $-0,1550$ \\
Harga jual koperasi & HRJK & 0,206161 & $<, 0001^{\mathrm{a}}$ & 0,5038 \\
Jumlah Anggota & JUAN & 0,885517 & 0,2531 & 0,0651 \\
Konstanta & & 13901,00 & $<, 0001$ & \\
\hline
\end{tabular}

$\mathrm{R}^{2}=0,47341$

Prob $>\mathrm{F}=<, 0001$

a) signifikan pada $\alpha=1 \%$, b) signifikan pada $\alpha=5 \%$ 
Tabel 4. Hasil pendugaan parameter faktor-faktor yang memengaruhi jumlah pembelian kopi

\begin{tabular}{lcccc}
\hline \multicolumn{1}{c}{ Variabel } & Simbol & Parameter dugaan & $\mathrm{P}>|\mathrm{t}|$ & Elastisitas \\
\hline Luas lahan binaan & LULB & 225,4398 & $0,0274^{\mathrm{b}}$ & 0,2900 \\
Harga beli koperasi & HRBK & $-57,5414$ & $0,0390^{\mathrm{b}}$ & $-0,8760$ \\
Jumlah penjualan koperasi & JJKK & 1,617285 & $0,0002^{\mathrm{a}}$ & 0,7021 \\
Konstanta & & 1364079 & 0,0521 & \\
\hline $\mathrm{R}^{2}=0.77391$ & & & \\
Prob $>\mathrm{F}=<.0001$ & & & \\
\hline
\end{tabular}

a) signifikan pada $\alpha=1 \%$, b) signifikan pada $\alpha=5 \%$

Harga pembelian kopi koperasi (HRBK) mempunyai pengaruh negatif terhadap jumlah pembelian kopi koperasi dan memiliki pengaruh signifikan pada taraf $\alpha$ 0,05. Perilaku koperasi dalam melakukan pembelian kopi sangat ditentukan oleh jumlah penjualan dan penawaran anggota yang kemudian akan mengarah pada harga yang dibayarkan oleh koperasi terhadap kopi anggota. Sesuai dengan teori permintaan, peningkatan harga akan menyebabkan penurunan terhadap permintaan. Namun demikian, jumlah pembelian kopi koperasi kurang responsif terhadap perubahan harga pembelian kopi. Koperasi melakukan pembelian kopi berdasarkan jumlah penjualan, apabila jumlah penjualannya meningkat maka koperasi akan meningkatkan jumlah pembelian sehingga peningkatan harga pembelian kopi oleh koperasi tidak akan menurunkan jumlah pembelian kopi karena koperasi harus memenuhi kontrak penjualannya. Hasil pendugaan parameter faktor-faktor yang memengaruhi jumlah pembelian kopi selengkapnya pada Tabel 4.

Jumlah Penjualan

Jumlah penjualan kopi koperasi (JJKK) merupakan jumlah penjualan kopi oleh koperasi kepada pembeli/ buyer. Dariketiga variabel yang diestimasimenunjukkan tanda parameter dugaan sesuai dengan hipotesis. Dari ketiga variabel tersebut, hanya satu variabel yang bepengaruh signifikan meningkatkan jumlah penjualan yaitu premium fee. Parameter dugaan premium fee (PREM) bertanda positif dan berpengaruh signifikan pada taraf $\alpha 0,01$. Premium fee merupakan insentif dari konsumen/buyer yang diterima koperasi dan kemudian akan distribusikan kepada anggota dari penjualan kopi dengan sertifikasi fairtrade. Nilai premium fee yang diterima adalah sebesar USD0,44 per kg kopi dari penjualan. Adanya peningkatan premium fee akan mendorong koperasi untuk melakukan penjualan yang lebih besar. Premium fee yang diterima koperasi terendah mencapai Rp200 juta rupiah per tahun dan tertinggi mencapai Rp168 milyar rupiah per tahun dengan jumlah penjualan rata-rata sebanyak 722 ribu $\mathrm{kg}$ kopi greenbean. Adapun hasil pendugaan parameter faktor-faktor yang memengaruhi jumlah penjualan kopi oleh koperasi dapat dilihat pada Tabel 5.

Rasio harga beli terhadap harga jual koperasi (RHJB) memiliki tanda parameter dugaan positif terhadap jumlah penjualan. Rasio harga menunjukkan kemampuan harga beli dan harga jual kopi dalam penjualan kopi koperasi. Peningkatan rasio harga ini akan meningkatkan jumlah penjualan kopi koperasi. Rata-rata harga pembelian kopi gabah oleh koperasi Rp26.911 per $\mathrm{kg}$ dengan harga penjualan kopi greenbean rata-rata sebesar adalah Rp61.133 per kg dimana jumlah penjualan rata-rata kopi greenbean adalah sebanyak 722 ribu kg per tahun.

Selanjutnya jumlah pembelian kopi koperasi (JBKK) mempunyai pengaruh positif terhadap jumlah penjualan kopi koperasi. Ketersediaan kopi anggota sangat menentukan jumlah penjualan kopi oleh koperasi, dimana koperasi sebelum melakukan penjualan atau pada saat koperasi akan melakukan kontrak, maka koperasi akan mengestimasi jumlah produksi kopi anggota sehingga koperasi dapat melakukan pembelian kopi. Sama halnya dengan jumlah pembelian kopi koperasi ditentukan oleh jumlah penjualan kopi maka peningkatan jumlah penjualan kopi koperasi juga ditentukan oleh jumlah pembelian kopi koperasi.

\section{Jumlah Anggota Koperasi}

Jumlah anggotakoperasi (JUAN) merupakan banyaknya anggota petani kopi pada koperasi. Hasil pendugaan parameter jumlah anggota koperasi menunjukkan variabel jumlah pembelian kopi koperasi (JBKK) berpengaruh positif dan signifikan pada taraf $\alpha \quad 0,05$ 
terhadap jumlah anggota koperasi. Hal ini menunjukkan bahwa besarnya jumlah anggota ditentukan oleh jumlah pembelian koperasi. Dari hasil perhitungan elastisitas pada jumlah pembelian koperasi menunjukkan bahwa variabel jumlah anggota responsif terhadap jumlah pembelian koperasi, ditunjukkan dengan nilai elastisitas lebih besar dari 1. Koperasi meningkatkan pembelian untuk pemenuhan kontrak penjualan maka koperasi mengumpulkan kopi dalam jumlah yang lebih banyak, dimana hal ini dapat dilakukan dengan menambah jumlah anggota. Semakin banyak jumlah pembelian maka akan meningkatkan jumlah anggota. Namun jika jumlah anggota tidak dibatasi (sesuai dengan prinsip koperasi) maka akan berimplikasi pada penurunan harga pembelian. Oleh karena itu, pembatasan jumlah anggota harus diperhatikan dalam koperasi agar koperasi dapat melakukan peran dan fungsinya sesuai dengan prinsip koperasi. Hasil temuan lapangan menunjukkan koperasi melakukan pembatasan terhadap jumlah anggota hal ini dengan mempertimbangkan estimasi jumlah produksi kopi untuk pemenuhan kontrak penjualan kopi koperasi.

Variabel harga pembelian kopi koperasi (HRBK) memiliki nilai parameter sebesar 0,009178 . Ini berarti peningkatan harga pembelian kopi oleh koperasi sebesar 1 satuan maka akan dapat meningkatkan jumlah anggota sebesar 0,009178 satuan. Hasil temuan pada lokasi penelitian bahwa kesesuaian harga yang diterima petani dari koperasi mendorong petani untuk bergabung dengan koperasi. Hasil pendugaan parameter faktorfaktor yang memengaruhi jumlah anggota koperasi pada Tabel 6 .

\section{Sisa Hasil Usaha}

Sisa hasil usaha koperasi (SHUK) merupakan pendapatan yang diperoleh koperasi dalam satu tahun. Variabel jumlah anggota koperasi (JUAN) memiliki tanda parameter dugaan tidak sesuai dan tidak signifikan terhadap sisa hasil usaha koperasi. Variabel jumlah anggota memiliki tanda negatif, artinya peningkatan jumlah anggota akan menurunkan sisa hasil usaha. Hasil ini berbeda dari penelitian Iramani dan Kristijadi (1997) yang menemukan jumlah anggota, volume usaha, jumlah simpanan meningkatkan sisa hasil usaha. Namun, hasil analisis yang tidak sesuai dengan hipotesis ini dapat dijelaskan dengan kondisi lapangan bahwa sebagian besar anggota koperasi masih kurang memiliki kesadaran untuk mengumpulkan simpanan wajib. Rata-rata iuran simpanan wajib pada koperasi berkisar adalah sebesar Rp5.000 hingga Rp15.000 per bulan dengan jumlah anggota koperasi rata-rata mencapai 1.732 orang. Simpanan ini merupakan salah satu sumber permodalan koperasi yang dapat digunakan untuk menjalankan aktivitas koperasi untuk memperoleh pendapatan.

Tabel 5. Hasil pendugaan parameter faktor-faktor yang memengaruhi jumlah penjualan kopi

\begin{tabular}{lcccc}
\hline \multicolumn{1}{c}{ Variabel } & Simbol & Parameter Dugaan & $\mathrm{P}>|\mathrm{t}|$ & Elastisitas \\
\hline Jumlah pembelian koperasi & JBKK & 0,103515 & 0,1737 & 0,2384 \\
Rasio harga & RHJB & 62965,89 & 0,8482 & 0,0401 \\
Premium fee & PREM & 0,000163 & $0,0003^{\text {a }}$ & 0,6660 \\
Konstanta & & 38292,47 & 0,8122 & \\
\hline
\end{tabular}

$\mathrm{R}^{2}=0,87264$

Prob $>\mathrm{F}=<, 0001$

${ }^{\text {a }}$ signifikan pada $\alpha=1 \%$

Tabel 6. Hasil pendugaan parameter faktor-faktor yang memengaruhi jumlah anggota koperasi

\begin{tabular}{lcccc}
\hline \multicolumn{1}{c}{ Variabel } & Simbol & Parameter Dugaan & $\mathrm{P}>|\mathrm{t}|$ & Elastisitas \\
\hline Harga beli koperasi & HRBK & 0,009178 & 0,9426 & 0,1247 \\
Jumlah pembelian koperasi & JBKK & 0,001616 & $0,0239^{\mathrm{b}}$ & 1,4426 \\
Sisa hasil usaha & SHUK & $-7,6 \mathrm{E}-6$ & 0,4062 & $-1,5309$ \\
Konstanta & & 1666,489 & 0,7208 & \\
\hline
\end{tabular}

$\mathrm{R}^{2}=0,21115$

Prob $>$ F $=0,0200$

${ }^{\mathrm{b}}$ signifikan pada $\alpha=5 \%$ 
Demikian juga dengan variabel lainnya yang diestimasi, keseluruhan variabel memiliki tanda parameter dugaan tidak sesuai dan tidak signifikan terhadap sisa hasil usaha. Hal ini mengindikasikan bahwa koperasi dalam menjalankan kegiatan usahanya tidak bertujuan memperoleh keuntungan sehingga kegiatan koperasi murni bertujuan untuk memberikan pelayan terbaik untuk anggotanya. Hasil ini menunjukkan temuan yang berbeda dari penelitian sebelumnya (Putri et al. 2013). Hasil ini mengindikasikan bahwa koperasi yang terdapat di kedua kabupaten tersebut telah menjalankan kegiatannya sesuai dengan fungsi dan prinsip koperasi. Hasil pendugaan parameter faktor-faktor yang memengaruhi sisa hasil usaha koperasi pada Tabel 7.

\section{Implikasi Manajerial}

Hasil penelitian maka implikasikasi manajerial yang dapat diambil adalah peningkatan harga pembelian kopi dapat dilakukan koperasi melalui peningkatan penjualan kopi. Koperasi dalam memasarkan kopi dapat membangun kerja sama kepada lembaga-lembaga terkait diatasnya (eksportir/buyer). Kerja sama ini akan menguntungkan petani (anggota) karena mempunyai jaminan pasar dan harga (meningkatkan bargaining position) dan; 2) Keberadaan koperasi memiliki peran penting dalam perekonomian masyarakat khususnya di dataran tinggi Gayo terutama dalam pemasaran kopi, oleh karenanya diperlukan peran pemerintah dalam mendukung sarana dan prasarana untuk kelancaran kegiatan koperasi tersebut.

\section{KESIMPULAN DAN SARAN}

\section{Kesimpulan}

Hasil dapat ditarik kesimpulan bahwa koperasi telah mampu meningkatkan harga kopi petani (anggota). Hal ini ditunjukkan dari perilaku koperasi dalam melakukan pembelian terhadap kopi anggota, dimana jumlah pembelian kopi koperasi dan harga jual kopi koperasi berpengaruh signifikan meningkatkan harga pembelian. Jumlah penjualan juga berpengaruh dalam meningkatkan jumlah pembelian kopi. Namun, jumlah pembelian, harga jual, harga beli dan jumlah anggota tidak berpengaruh dalam meningkatkan sisa hasil usaha koperasi. Hal ini mengindikasikan bahwa koperasi telah menjalankan fungsi dan perannya sesuai dengan prinsip-prinsip koperasi dalam melayani kebutuhan anggota.

\section{Saran}

Hasil penelitian dan kesimpulan maka dapat disampaikan saran bagi pemerintah Indonesia dan penelitian lanjutan. Adapun saran tersebut sebagai antara lain kebijakan pengembangan koperasi perlu dilakukan melalui pembinaan/pengawasan dan bantuan permodalan. Hal ini bertujuan agar koperasi dapat terus melakukan kegiatan usahanya sesuai dengan prinsipprinsip koperasi sehingga akan berdampak terhadap peningkatan bargaining position petani. Selanjutnya, saran untuk penelitian lanjutan diharapkan dapat melihat peran koperasi dalam unit masing-masing koperasi sehingga dapat mempelajari perilaku koperasi secara spesifik.

Tabel 7. Hasil pendugaan parameter faktor-faktor yang memengaruhi sisa hasil usaha koperasi

\begin{tabular}{lcccc}
\hline \multicolumn{1}{c}{ Variabel } & Simbol & Parameter dugaan & $\mathrm{P}>|\mathrm{t}|$ & Elastisitas \\
\hline Harga jual koperasi & HRJK & $-5776,49$ & 0,6178 & $-0,9526$ \\
Harga beli koperasi & HRBK & 23303,99 & 0,6888 & 1,5724 \\
Jumlah anggota & JUAN & -153913 & 0,6078 & $-0,7640$ \\
Jumlah pembelian koperasi & JBKK & 492,9775 & 0,5802 & 2,1848 \\
Premium fee & PREM & $-0,13672$ & 0,6651 & $-1,0749$ \\
Konstanta & & 11979100 & 0,9895 & \\
\hline $\mathrm{R}^{2}=0,04590$ & & & \\
Prob $>\mathrm{F}=0,8626$ & & & \\
\hline
\end{tabular}




\section{DAFTAR PUSTAKA}

[BPS] Badan Pusat Statistik. 2015. Statistik Perkembangan Koperasi 2014. Jakarta. Badan Pusat Statistik.

Cook M. 1995. The role of management behavior in agricultural cooperatives. Jurnal of Agricultural Cooperation 9:42-66

[Disbun] Dinas Perkebunan Provinsi Aceh. 2013. Prospek Pengembangan Kopi Arabika Gayo di Kabupaten Aceh Tengah dan Bener Meriah. Aceh. Aceh: Dinas Perkebunan.

Dahl DC, JW Hammond. 1977. Market and Price Analysis. The Agriculture Industries: Marketing and Price Institusions. NewYork: McGraw-Hill.

Fatwa Z. 2011. Analisis fungsi produksi dan efisiensi usaha tani kopi rakyat di Aceh Tengah [tesis]. Bogor: Sekolah Program Pascasarjana, Institut Pertanian Bogor.

Goldsmith PD. 1995. Business behavior as a function of business stucture: a transaction theory of cooperative firm [dissertasion]. The Ohio State University. Reprinted by Electronic Order from University Microfilms International: Michigan, USA.

Hasan I. 2014. Analisis kinerja koperasi pertanian dalam tataniaga komoditas ekspor di Kabupaten Aceh Tengah-Provinsi Aceh dalam menghadapi persaingan antar negara asean 2015. Jurnal Kebangsaan 6 (3):1-12.

Helmberger PG, Hoos S. 1962. Cooperative enterprise and organization theory. Jurnal of Farm Economics 44: 90-275. https://doi. org/10.2307/1235830.

Iramani, Kristijadi E. 1997. Faktor-faktor yang memengaruhi sisa hasil usaha koperasi unit desa di Jawa Timur. Jurnal Ventura1(2):73-79.

Krisnamurthi B. 1998. Perkembangan kelembagaan dan perilaku usaha koperasi unit desa di Jawa Barat; suatu kajian cross-section [disertasi]. Bogor: Sekolah Program Pascasarjana, Institut Pertanian Bogor.

Ketaren N. 2007. Faktor-faktor yang memengaruhi keberhasilan koperasi credit union dalam pemberdayaan masyarakat (studi kasus: koperasi credit union sukamakmur Kecamatan Sibolangit, Kabupaten Deli Serdang). Jurnal Harmoni Sosial 1(3): 138-146.
Katz J. 1997. Managerial behavior and strategi choice in agribusiness cooperatives. Agribusiness an International Journal 13(5):483-495.

Levay C. 1987. Agricultural cooperation theory: a review. Journal Agricultural Economics 6(20):27-49.

Mujiburrahan. 2011. Sistem jaringan pasok dan nilai tambah ekonomi kopi organik (studi kasus di KBQ baburrayan Kabupaten Aceh Tengah). Jurnal Agrisep 12(1): 1-10.

Murray GC. 1983. Management strategies corporate control in british agricultural cooperative. Agricultural Administration Journal 14(2): 81-94. https://doi.org/10.1016/0309-586X(83) 90033-X.

Putri MA, Fariyanti A, Kusnadi N. 2013. Struktur dan integrasi pasar kopi arabika gayo di Kabupaten Aceh Tengah dan Bener Meriah. Buletin RISTRI 4(1): 47-54.

Subari S. 2012. Faktor-faktor yang memengaruhi kinerja koperasi nelayan dalam upaya peningkatan kesejahteraan anggota. Jurnal Agriekonomika 1(1):25-35.

Saputra A. 2012. Desain rantai pasok kopi organik di Aceh Tengah untuk optimalisasi balancing risk [tesis]. Bogor: Sekolah Pascasarjana, Institut Pertanian Bogor.

Staatz JM. 1987. Recent development in the theory of agriculture cooperation. ACS Research Report (84): 1-25.

Sarjana IM, Susrusa BK, Darmawan DP. 2013. Analisis keuangan pada koperasi serba usaha di Kabupaten Buleleng. Jurnal Manajemen Agribisnis 2(2) :16-22.

Sexton R. 1984. Perspective on the development of the economic theory of cooperative. Canadian Journal of Agricultural Economics 32(2): 423436. https://doi.org/10.1111/j.1744-7976.1984. tb02135.x.

Wollni M, Zeller M. 2007. Do farmers benefit from participating in specialty markets and cooperatives? The case of coffee marketing in Costa Rica. Journal Agricultural Economics 37(2): 243-248. https://doi.org/10.1111/j.15740862.2007.00270.x.

Wijaya M. 2004.Pengembangan potensi ekonomi rakyat melalui gerakan koperasi dalam menghadapi otonomi daerah. Jurnal Sosiologi Dialektika Masyarakat 17(1): 27-31. 